\title{
USING LAY VOLUNTEERS TO REPRESENT CHILDREN IN CHILD PROTECTION COURT PROCEEDINGS
}

\author{
DonALD N. DuQuetTE. J.D. \\ Clinical Professor of Law. Director. Child Advocacy Law Clinic, Lniversity of Michigan Law School. Ann \\ Arbor. $.11+8109-1215$
}

\author{
SARAH H. RAMSEY, J.D. \\ Associate Professor. Syracune College University of Law, Syracuse, NY
}

\begin{abstract}
Despite a widespread conviction that children ought to be independently represented in child protection court proceedings in the United States, there is little consensus as to what the role of that independent child advocate ought to be or, indeed. who should fulfill that role. This study accomplished three purposes: (1) articulated an aggressive, ambitious and continuous role for the child's representative which encompassed a broad range of the child's interests, both legal and nonlegal: (2) provided training in this role to demonstration groups of attorneys, law students and lay volunteers; and (3) compared the effectiveness of each of the three demonstration groups in representing children to one another and to a control group of attorneys who received no special training from the research tearn. The findings indicate that carrefully selected and trained lay people representing children in child abuse and neglect legal proceedings under lawver supervision performed similarly to trained lawyers and law students in the way they approached their duties and in case outcomes achieved and significantly different from attorneys who, consistent with the practice in nearly all the United States. received no special training in child advocacy.
\end{abstract}

Résumé-ll existe une croyance généralisée selon laquelle les enfants devraient être représentés de façon indé. pendante dans les audiences des tribunaux chargés de la protection de lenfance aux Etats-Ĺnis. Cependant personne n'est d'accord sur le robe que doit jouer le défenseur indépendant de lenfant dans ces tribunaux ni non plus sur la défnition de la personne qui doit jouer ce róle. Létude presentée ici a atteint les buts suivants: (1) Elle a défini un röle agressif. ambitieux, ininterrompu pour le représentant de l'enfiant. röle tenant compte dans une large mesure des intérêts de l'entän à la fois juridiques et non juridiques. (2) Elle al été didactique, par la création de groupes de démonstration composés d'avocats, d'étudiants en droit. et de personnes bénévoles non professionnelles. (3) Elle a permis de comparer l'efficacité de chascun des trois groupes de démonstration dans leur tentative mutuelle de représenter les enfants; un groupe de juristes qui navaient pas reçu une formation particulière de la part de l'équipe conduisant la recherche, a servi de groupe témoin. Il est apparu daprès cette étude que des bénévoles bien choisis et bien entrainés chargés de représenter les intérèts des entants dans les cas de maltraitement ou de négligence venant devant les tribunaux, a condition quils soient guidés par un avocat, s'en s'ont tirés au moins aussi bien que les avocats et les étudiants en droit ayant subi une formation spéciale. Ces bénévoees ont démontré une compétence certaine dans la façon dont ils ont conçu leurs responsabilités et ils ont obtenu des résultats en audience nettement meilleurs que les avocats qui eux n'avaient reçu aucune formation dans le róle de défénseur d’enfants. Les juristes américains sont mal préparés à assurner le rôle de représentants des enfants maltraités ou négligés devant les tribunaux.

\section{THE PURPOSES OF THE STUDY}

WHAT SHOULD BE the duties and responsibilities of the child advocate in civil child protection proceedings? Who should represent the child in such cases? How can effective representation of the child be accomplished? This study accomplished three purposes: (1)

The research reported here was awarded the 1985 Research in Advocacy Award by the National Court Appointed Special Advocate (CASA) Association. 
conceptualized the role of the child's representative ats aggressive. ambitious and encompassing a broad range of the child's interests - both legal and nonlegal: (2) provided training in this role to demonstration groups of attorneys. law students and lay inonlawyer) volunters: and (3) compared the effectiveness of each of the three demonstration groups in representing children to one another and to a control group of attorneys who received no special training from the research team.

\section{Search for Alternative Representation for Children}

Most people recognize the need for children to be independenty represented in child abuse and neglect proceedings $[1-4]$ but dissatisfaction with the representation as it is currently provided is widespreat $[5-10]$. There is no consensus on what the role and responsibility of the child s representative ought to be and little consistency among lawyers in fulfilling this responsibility or in preparing for it [11-12]. There is little in the education and training of lawyers that necessarily enables them to properly serve the special interest of the child [13] and because law schools usually do not provide tratining in this nontraditional role. "many lawyers are uncomfortable with the nonlegal responsibilities they may have in abuse and neglect cases" [14]. The dissatisfaction and uncertainty about the role of the child's representative hats provided an impetus for clarifying those duties and responsibilities and for searching for alternative ways to represent children.

The CASA movement. The search for ways to improve the representation of children in child abuse and neglect court procecdings has taken many forms. Communities throughout the United States have experimented with trained lay volunteers to either represent the child or to assist a lawyer in representation of the child. Seattle. Washington, began its Gualdian ad Litem Program in 1977 using the title. court appointed special advocate (CASA) to designate the lay volunteer who represents children in child protection cases [12, 15]. These Seattle CASAs. who worked under the supervision of a social worker and a lawyer, were viewed as a substitute for court-appointed lawyers for children [15].

The National Council of Family and Juvenile Court Judges (NCFJCJ) has encouraged CASA program development in many ways, including sponsoring national CASA seminars and programs | 6 6. NCFJCJ also developed an earlier volunteer child advocate program called the Children in Placement Program (CIP), a post-disposition monitoring process in which a trained lay volunteer tracked children placed out of their homes and adrocated for meaningful court review of each child's placement with a goal of returning the child to his original family as soon as possible or moving to free the child for adoption [17]. NCFJCJ, among others, has actively pressed for use of lay volunteers in foster care review boards which are active in several jurisdictions [18]. The National Council of Jewish Women, having adopted CASAs as a special community service project, developed an extensive manual for CASA programs and sponsored programs around the country [19]. Over 173 such programs now exist in 39 states [20]. An active Vational Association of Court Appointed Special Advocates has been organized that provides a national newsletter. an annual meeting and other services [21].

The role of CASAs and other lay volunteer child advocates varies greatly from community to community. The volunteer may operate independently or may be paired with an attorney and become the "eyes and ears" of the child's legal representative. doing separate investigations and independent advocacy for the child. Still other volunteer advocates function as assistants or adjuncts to caseworkers. 
Non-lawer representation of children. The question of whether someone other than a lawyer should represent the children has been raised in several quarters. The ABA Juvenile Justice Standards Project comments:

While independent representation for a child may he important in prosective and custodial provedings, at representative trained wholly in law mity not be the appropriate choice for this function.

Accordingly it would not seem irresponsible to suggest that a protessional trained in psychology. psychiatry. social psychology or social welfure be assigned the initial responsibility for protecting children under these circumstances. There is, however, no evidence that this alternative is presently available. either in terms of numbers of competent personnel or in terms of occupational independence from official and interested agencies.

. until there are sutticient numbers of independent, competent personnel trained in other disciplines who will undertake to ascertain and guard the child's interests in these proceedings, continued reliance on legal representation for the child is necessary. [22, 23]

To encourage exploration and evaluation of alternative ways of providing representation to children, the National Center for Child Abuse and Neglect (NCCA.N) funded 28 demonstration projects around the country since 1978 in which children are represented by volunteer lawyers. law students. multidisciplinary child advocate offices. and lay volunters [24]. The study reported here is one of these.

\section{ROLE DEFINITION OF THE CHILD ADVOCATES}

Before addressing the question of a training curriculum for child adrocates, some working assumptions about the role of that representative and about what might constitute the child"s "best interests" were developed. The study began with a detinition of the child advocate role that is aggressive, ambitious, continuous, and encompasses both legal and nonlegal interests of the child. That is. advocacy for a child, under this role definition, emphasized the personal interests of the child and was broadly defined to include not just courtroom advocacy but also out-of-court advocacy with agencies and other service providers and in informal meetings and telephone calls with social workers and other parties to the case. This model emphasized the interests and needs of the child beyond those typically identified by statutes and court rules.

\section{Seeking the "Best Interests of the Child"}

A major ambiguity in representing children in court stems from the admonition to represent the "best interests" of the child. But what are the child's best interests"?

Deciding what is best for a child otten poses a question no less ultimate than the purposes and values of life itself. Should the decision maker be primarily concerned with the child's happiness or with the child's spiritual and religious training? Is the primary goal long-term economic productivity when the child grows up? Or are the most important values of life found in warm relationships? In discipline and self-salcrifice? Are stability and security for a child more desirable than intellectual stimulation? These questions could be elaborated endlessly. And yet. where is one to look for the set of values that should guide decisions concerning what is best for the child?. . . Ilf one looks to our society at large, one finds neither a clear consensus as to the best child-rearing strategies, nor an appropriate hierarchy of ultimate values. $[25,26]$

Thus, "best interests" is far from being an objective legal standard, but is instead a statement of a very nebulous goal. Nonetheless. even recognizing the imprecision and indeterminance of the best interests standard, the advocates were trained in identifying and pursuing goals which the research team. based on their experience. believed most likely to be "best" for most children. Public Law 96-272 (Adoption Assistance and Child Welfare Act of 1980) and its underlying rationale provided the basis of many of the sub- 
jective choices as to what is likely to be in the best interests of most children. Individual judgment on behalf of specific children remained necessary however. The training received by the demonstration groups was intended to provide a basis for making their own judgments and for evaluating the judgments made by others such as social workers and court officials.

\section{Identifing the Interest of the Child}

Certain interests of the child were emphasized by the project including the importance of a careful assessment of the family situation and development of timely and specific case plans. The project emphasized that the child's interests included preserving his placement with his parent or parents, if at all possible, consistent with his well-being and safety. A "child's sense of time" [27] was discussed to demonstrate that if the child is removed from his family it should be for the shortest time possible and his placement should generally be one that is the most familiar to him (the least restrictive. most familylike setting) [28-30]. Contact with the family should ordinarily be maintained through regular visits. If services to the child or his family were needed before he could return home. the project recommended that they should be identified accurately and provided promptly.

Certainly to be protected from physical and emotional harm and to be provided minimally adequate food. clothing, shelter, guidance and supervision is in the child"s "best interests." The social worker and the court generally addressed obvious deficiencies in the child's care in these areas without the need for intervention by an independent child's representative. Other interests are more subtle however, and may easily be overlooked by all but the child's representative.

The state intervention itself presents additional risks to the child for which the child advocate must be wary. The demonstration groups were advised that the interests of the individual child are not always consistent with those of the state agency. Because of high caseloads, agencies may be unwilling or unable to meet each child's individual needs, e.g. for frequent visitation. An overburdened caseworker may not be as sensitive, as careful, or as skilled in judgment as she or he would be under less taxing circumstances. Consequently, the child runs the risk of either being inappropriately separated from his familiar surroundings or of having an inadequate assessment of his home situation. so that remedies prescribed are inappropriate, inadequate or too late. If the child is removed from home, the child runs the risk of being placed in multiple foster homes. of being abused in foster care, of being placed in inappropriate institutions, and of not having visits with his parents and family often enough. Reasonable case plans may be developed by social agencies but not be implemented properly or quickly, thus adding to the length of time the child is out of his home and lessening the child's chances of ever returning home.

In coming to a "best interests" position for the child. the child's representatives were trained to ascertain the facts of the case as clearly as possible by interviewing family members, neighbors, and others as necessary. The suggestion was made that the representatives also might rely on a thorough protective services investigation in some circumstances. The child advocate was advised to meet the child client in every case even if the child was an infant, if only for the purpose of getting a feel for the child as a real person facing a serious personal problem. The goal was to personalize the child to the advocate beyond the paper work of court petitions and social work reports.

\section{Wishes of the Child is. Best Interests}

The traditional lawyer role is to advocate for goals as defined by the client. In some cases what a child wished to see happen would, in fact, be "best" for the child in the eyes of the lawyer, but this would not always be true. If the child wanted to go home, for 
example, but the child advocate felt that the home was unsafe, there would be a conflict between the child's wishes and the representative's view of the child's best interests. In a situation where the advocate pressed for a position inconsistent with what the child wanted, the child would effectively be denied a voice in the legal proceedings.

The project responded to this ambiguity by taking a flexible, child-centered approach to representation. Advocates were expected to always meet the child and. to the extent possible, find out what the child wanted. The wishes of a child were treated with respect and. with older children, would typically guide the representative's actions. In the case of young children, those under age 9 or so. representatives considered what the child's wishes were but typically advocated what the representative identified as the client's "best interests" [26,31-34].

\section{Independence of the Child Advocate}

The project stressed that the child's representative ought not agree with the social worker's recommendations without question. While maintaining a cooperative spirit, the representative should question the worker closely and extract the underlying basis for the caseworker's positions and recommendations. The advocate's conclusions should be reached independently. The advocate should strive to identify what the determinates of the problem are. Once the underlying determinates are identified, the advocate can help discover ways to ease them. Thus, the demonstration child advocates were encouraged to take a broad view of the child's interests, in the context of his family and to avoid a piecemeal approach to the child and his family's problems.

\section{TRAINING PROVIDED}

\section{Idemification of Needs and Interests of Children}

The demonstration child advocates were given training intended to help them identify the needs and interests of their young clients. Films, lectures, discussions, and exercises reviewed the causes and dynamics of child abuse and neglect; suggested a process of investigation and assessment; identified aspects of child development most relevant to determining the child's psychological needs at various ages; and described intervention programs available locally that might assist families and their children.

The demonstration attorneys and the volunteers received four days of training from the University of Michigan Law School Child Advocacy Program between January 27 and February 11, 1982. The law students received similar training in their coursework at the Child Advocacy Law Clinic. All participants were given a copy of a book on social work with abused and neglected children that included contributions from a number of disciplines on topics such as sexual abuse and child development [36].

The importance of assessing parental conduct, appraising the risks to a child presented by environment, recognizing strengths in the parent-child relationship, and evaluating the soundness of an intervention strategy proposed by the social agency were emphasized. The representatives were taught that they must synthesize the results of the protective services investigation; the child's psychological, developmental, and physical needs; the child's articulated wishes; the representative's own assessment of the facts and of the treatment resources available.

\section{Adrocacy Training}

In addition to being trained to identify the needs and interests of the child, the demon- 
stration groups also were tratined to advocate vigorously for those interests - both in the courtroom and within the child samily, with the court workers and the social agencies involved. They were taught that adrocacy for the child ought to begin with the social agency which tiled the petition. The child's representatives were advised to advocate in and out of court for careful assessment of the family situation, for adequate and specific case plans, and for timely implementation of the case plans.

The representatives were asked to play a significant role in facilitating negotiation and mediation. They were taught that swift resolution of the legal dispute which is as cooperative and as nonadversarial ats possible and which provides the needed protection and services to the child is nearly always in the child's interest. The child's representatives were trained to encourage negotiation and to play the role of mediator and conciliator between the social ageney and parents.

In court hearings the child's representatives were instructed to ensure that all the relevant facts were brought before the judge and to advocate for a resolution of the case most likely to achieve the identified interests of the child.

\section{Follow-up and Continuity.}

After adjudication. the child's representative was to remain vigorous and active. The child advocate was asked to press and persuade the responsible social agencies for the services and attention that the child client fand perhaps his family) needed. Preferably: such nudging would be done in a collegial, nonaceusatory manner but if social workers or agencies were not fulfilling their responsibility to a particular child (or to his parents), the child s representative was asked to insist on a higher standard of seviec either by a direct request to supervisors in the agency or by formally rasing the issues before the court.

An additional concern of the project was that the child should have continuity in representation. Continuty would allow a representative to have the benetit of investigation and experience with the case over time and would result in a better-informed advocate. Additionally. the project felt that continuty would result in a better client-representative relattionship, and in fewer delays in court procedings. Conscquently the representatives were tanght that they were expected to serve for the duration of the case.

In summary, the training incotporated the project's concept of the proper role of the representative: a child-centered advocate who understood the social-psychological problems involved in the case. Who understood the importance of the social service agencies in case resolution. and who was committed to actively guiding the case through to its end [37].

\section{STUDY DESIGN}

This study demonstrated the effects of training three different kinds of advocates for allegedly abused and neglected children in Genessee County Juvenile Court (Flint. Michigan). A goal of the study was to provice evidence as to whether some alternative to lawyer representation is both feasible and consistent with high standards of performance on behalf of the child. The demonstration groups included the following: (1) private attorneys selected at random from the court list of attorneys interested in accepting appointments in child abuse and neglect cases: (2) law students from the University of Michigan Law School Child Advocacy Law Clinic: and (3) lay volunteers under the supervision of an experienced attorney.

Under the existing system, attorneys were appointed by the court on a rotating basis to represent children. The attorneys typically were general practitioners who had no special 
training in child abuse and neglect. Additionally. the attorneys did not follow a case through the entire court process. Instead. one attorney was appointed for the preliminary hearing and another was appointed to serve at subsequent hearings.

The demonstration groups differed in three respects from the existing system. First. a number of the representatives were not attorneys. but rather lay volunteers under lawyer supervision or law students from the University of Michigan Law School Child Advocacy Law Clinic. Both non-attorney groups assumed primary responsibility for the investigattion and decision making in their cases. Secondly, the research team provided the demonstration child advocates with four days of training (or its equivalent in the case of the law students) as described above. Thirdly, the demonstration child advocates served for the duration of the case.

\section{Selecting and Supervising the Volunteers}

Assisted by several community volunteer organizations, the project sought lay volunteers experienced in dealing with children, with formal social systems, and with the court. and for individuals whose attitudes toward child abuse and neglect was family-oriented. rehabilitative yet philosophically recognizing the need for a child to be removed from his family in some circumstances either temporarily or permanently. Ten persons received four days of taining and began to represent children. The volunteers worked in teams of two initially and then alone. Becaluse of time commitments and scheduling problems, five of the initial ten voluntecrs working alone or with a partner handled all the volunteer cases. The volunteers included a retired General Motors supervisor, a homemaker with a master's degree in education who was taking time out from the work force until her children were older, an executive director of a social services agency, a journalist, a college senior majoring in psychology, a former juvenile court caseworker, a department store employec, and a General Motors production worker.

The lay volunteers were supervised by an attorney in private practice who had training and experience in representing children and who appeared as the attorney of record. The supervising attorney conterred frequently with the lay volunteers as they were investigating and preparing their cases. Even as the lay volunteers gained experience, they continued to have questions about court procedure. He accompanied the volunteers in their first court appearances. Subsequently, however, he made a determination as to whether legal questions or taking of testimony required his presence. If not, he would allow the volunteer to appear in court without him. Volunteers appeared without the supervisor approximately $35 \%$ of the time. The court appearances without the supervising attorney increased as the volunteers gained experience. Even if the lawyer appeared, the volunteers presented their recommendations to the court and the lawyer rarely had to make any comments on the record. The lawyer dealt with legal issues or the taking of testimony in the few cases in which that was necessary. If the lawyer did not appear in court on a case, he remained on-call in his nearby office.

The lay volunteers had primary responsibility for representing the children with the lawyer acting in a supervisory and advisory capacity only. Although the supervisor responded to questions of law and procedure and discussed each case with the volunteers. he did not find it necessary to override any volunteer's assessment of a case or his/her proposed recommendations to the court. Occasionally the volunteer and supervisor differed on what course of action was best for a child. i.e.. whether to keep the child in foster care or return him home. In no case, however. was the judgment of the volunteer on such nonlegal matters not accepted by the lawyer. The supervising attorney's attitude, and that espoused by the research team. was that the volunteers' judgments, given their individual backgrounds, training and personal contact with the case, were as good as, if not better than, the attorney's in the nonlegal areas. 


\section{Data Set}

The control group consisted of 38 cases of alleged child abuse and neglect active between August 1. 1981 and October 31. 1981 and handled by attorneys who received no intervention from the research team. The demonstration groups included 53 cases active between February 1,1982 and December 31. 1982: 16 cases handled by law students: 22 handled by volunteers: and 15 handled by the trained lawyers. All cases were heard by the same judge, Probate Judge Thomas L. Gadola. There were no changes in the local court processes, statutes. or rules governing child protection cases during the 18 months in which data collection for control and demonstration cases took place. Staff level and the operating budgets for the court and department of social services remained approximately the same during this period. A comparison of control and demonstration cases revealed no significant differences as to the types of abuse and severity of the types of abuse. There also were no significant differences between the demonstration and control groups on race, sex, and the mean number of children per case [38]. Thus the basis for comparing the control and demonstration groups seems reasonably strong.

\section{Measures}

Process measures and outcome measures were developed to evaluate the performance of the child advocates. To evaluate the process of representation, i.e.. what the advocates actually did to advocate for their young clients, the researchers conducted a face-to-face 45-minute interview with each representative using an instrument with structured and open-ended questions for each case that was handled. Eight different measures of outcome were developed relying on the court orders and court records of each case.

\section{MAJOR FINDINGS: PROCESS MEASURES}

Information on the steps the advocates took to represent a child came from individual 45-minute interviews with each advocate on each case. Through the statistical technique of factor analysis, questions that actually were measuring the same underlying dimension of any activity or attitude were combined into one, more accurate, condensed scale. Using factor analysis, four standardized scales were developed [39]:

Factor 1, Investigation-Interaction Scale, a measure that combines the number of people representatives talked to, the total number of sources of factual information, the number of persons who urged the representatives to accept their recommendations fan indication of the representative's interaction with others), and the total number of hours spent on the case.

Factor 2, Adrocacy Scale, a measure that combines the number of recommendations made by the representative, the number of services obtained and the number of people monitored by the representative after the first major disposition.

Factor 3, Motivation Scale, a combination measure indicating the degree to which the representatives saw their role as important, were highly interested in the case and were more likely to characterize their role at the hearings as active rather than passive or neutral.

Factor 4. Child Scale, a measure that combines whether or not the representative met with the child, the percent of time spent talking with the child, the rank of the child as an 
important source of information. the utility of contact with the child, and the degree of consideration given to the child's wishes.

Other variables that were not related to these four scales, but were of theoretical or practical significance. were retained and examined separately. For the purpose of discussion. these other variables and the factor scales were placed in the following four broad categories of process measures:

1. Investigation/Advocacy/Mediation:

2. Representative's Attitude Toward the Role:

3. Representative's Attitude Toward the Child:

4. Representative's Attitude Toward Others.

The factor scales and variables which are in each of these four categories are listed in Table 1. and include any process measure that, when used as a basis for comparison among the three demonstration groups or of the combined demonstration group with the control group, resulted in differences that were statistically significant.

\section{Differences Among Demonstration Groups}

After comparing the three demonstration groups on process measures only a few significant differences emerged. The law students scored higher on the investigation-interaction scale than either of the other groups and tried to convince more people and took significantly more actions to attempt mediation than did the volunteers. Law students were more critical of the other actors in the process than either the trained lawyers or the volunteers. Both law students and volunteers were more likely than attorneys to feel that their activity as the child's advocate made a difference in the outcome of the case for the child.

Table 1. Four Categories of Process Measures

1. Investigation/Advocacy/Mediation

Investigation/Interaction Scale (Factor I)

Advocacy Scale (Factor 2)

People Tried to Convince the number of different persons the representative tried to convince to accept his or her recommendations)

Follow-up Activitics (yes or no)

Sum of Mediation Actions (number of different actions representative took to try to get the parties to agree. for example phone calls, meetings)

Role in Getling Services (Did the representative play a role in getting the court to order services-yes or no)

2. Representative's Altitude Toward Role

Motivation Scale (Factor 3)

Outcome Different because of Child Advocate (Did the representative think hisher presence made a difference in outcome-yes or no)

Satisfaction with Outcome (Was the representative satisfied with the outcome of the case-rating on five point scale - not at all to very much).

3. Representative's Attitude Toward Child

Child Scale (Factor 4 )

Purpose of Representative's Contact with Child:

State Recommendations (yes or no)

Assessment (yes or no)

4. Representative's Altitude Toward Others

Courtworker's Competency (rated on 5 point scale-very low to very high)

Prosecutor's Competency (rated on 5 point scale-very low to very high)

Social Service Worker's Competency (rated on 5 point scale - very low to very high)

Responsiveness Agency/Court Personnel (rated on 5 point scale-very low to very high)

Proceedings Moved too Slowly (yes or no) 
Overall. these few differences were not great enough to conclude that the performance of one demonstration group was substantially different from the performance of any of the others. The lay volunteers. the law students and the trained attorneys performed similar activities while representing their child clients. Given these few differences. we felt it reasonable to combine the three demonstration groups for comparison with the control groups on the process measures.

\section{Differences Between Demonstration Group and Controls}

There were many significant differences 1.05 or better) between the demonstration groups and the control group on process measures. The demonstration group spent more time on their cases. For cases dismissed at preliminary hearing. the demonstration advocates spent a mean of 5.5 hours compared to a mean of 1 hour for the control. For cases going beyond preliminary hearing. the demonstration group spent a mealn of 8.5 hours vs. 5.6 for the control. The demonstration group scored higher on the Investigation-Interaction Scale (indicating that they spent more time on the case, talked to more people, relied upon more sources of information and more people urged them to accept recommendations). The demonstration groups took more steps to mediate disputes at preliminary hearings, were more critical of the other actors in the process, and were more likely to engage in follow-up activities on behalf of their young clients. On cases that went beyond preliminary hearing, the demonstration child advocates rated higher on the motivation scate (i.e. saw their role as more important), and on the advocacy scale (indicating that they made more recommendations, obtained more services for their clients and monitored more persons after the first major disposition).

In all, the demonstration child advocates" performance when contrasted with the control group was in keeping with the role of the child advocates presented by the training. Thorough investigation, active advocacy and a skeptical but active role with others in the proceedings was characteristic of the representation provided by each group of the demonstration child advocates.

\section{MAJOR FINDINGS: OUTCOME MEASURES}

Eight different measures of outcome were developed relying on the court records of each case. The outcome measures were designed to compare the actual management and resolution of the control and demonstration cases as reflected by the court's own orders. The outcome measures are

- Court Processing Time;

- Placement Orders: Home, Relative, or Other:

- Visitation Orders:

- Treatment/Assessment Orders;

- No Contest Pleas;

- Ward of Court;

- Dismissals;

- Other Procedural Orders.

In what may be the most important finding, no significant differences were found among the demonstration groups on outcome measures. That is, the case outcomes achieved by lay volunteers. lawyers and law students on behalf of their young clients were comparable. Since there were no significant differences on outcome measures 
among the demonstration groups, they were combined for purposes of comparison with the control attorneys on outcome measures.

\section{Path Analysis}

There were, however, a good number of significant differences between the control group and the demonstration groups. Rather than simply comparing the demonstration and control child advocates on outcome measures in a bivariate analysis, a multifactor or multivariate path analysis was pursued to examine the causal link between the treatment given to the demonstration groups (i.e.. the training) with the case outcomes. The training changed how the demonstration child advocates handled their cases and this change in advocacy, in turn, affected outcome. Multivariate techniques made it possible to estimate and evaluate the strength, direction and significance of the specific steps the child advocates took which contributed to the case outcomes [40]. To simplify analysis, the only process measures that were used for path analysis were the four factor scales: Investigation-Interaction. Advocacy. Motivation and Child [41]. Only two of these, InvestigationInteraction and Advocacy, were found to influence the outcome measures.

The effect of type of child representative (control or demonstration) and of child representation activities (process variables) on case outcome measures are presented in Figure 1. Figure 1 gives the Bet a weights (standardized regression coefficients) for each relationship. Beta weights range from a high of +1 to a low of -1 . An advantage of the standardized score is that the strength and direction of the relationships among all of the variables in the model can be compared easily. For example, there is a strong positive relationship between the process measure. Investigation-Interaction, and the outcome measure. Home Placement $(+.3)$; but a relatively weak positive relationship between Investigation-Interaction and Other Placement $(+.12)$.

The analysis strowed that the demonstration representatives did have an impact on a number of aspects of case outcome. This effect was sometimes directly related to the type of representative. For example, children represented by the demonstration representatives were less likely to be made wards of the court than were the children represented by the control representatives. This may have been due to the continuity of representation provided by the demonstration representatives, to their overall activity, or to some combination of these factors.

However, more often this effect was indirect; that is, the demonstration representatives performed differently as measured by the process variables and this difference in representational processes resulted in a change in the outcome variables. For example, the demonstration representalives were more likely to have a high score on the Advocacy Scale and a high score on the Advocacy Scale was positively related to Treatment/Assessment orders.

Court processing time. Court processing time was influenced by the representatives' activity as measured by the Advocacy Scale. When representatives scored high on the Advocacy Scale, the number of days in the system was significantly reduced. Further, as reported above, the demonstration representatives scored significantly higher on the Advocacy Scale. In other words, while the type of representative did not directly influence court processing time, the demonstration treatment did result in more advocacy which, in turn, produced a reduction in the number of days between the filing of the petition and the first major disposition. Delays can be very harmful to children by causing longer than necessary out-of-home placement and other disruptions to the child's stability and continuity. The advocacy activities of the demonstration groups resulted in their cases pro- 


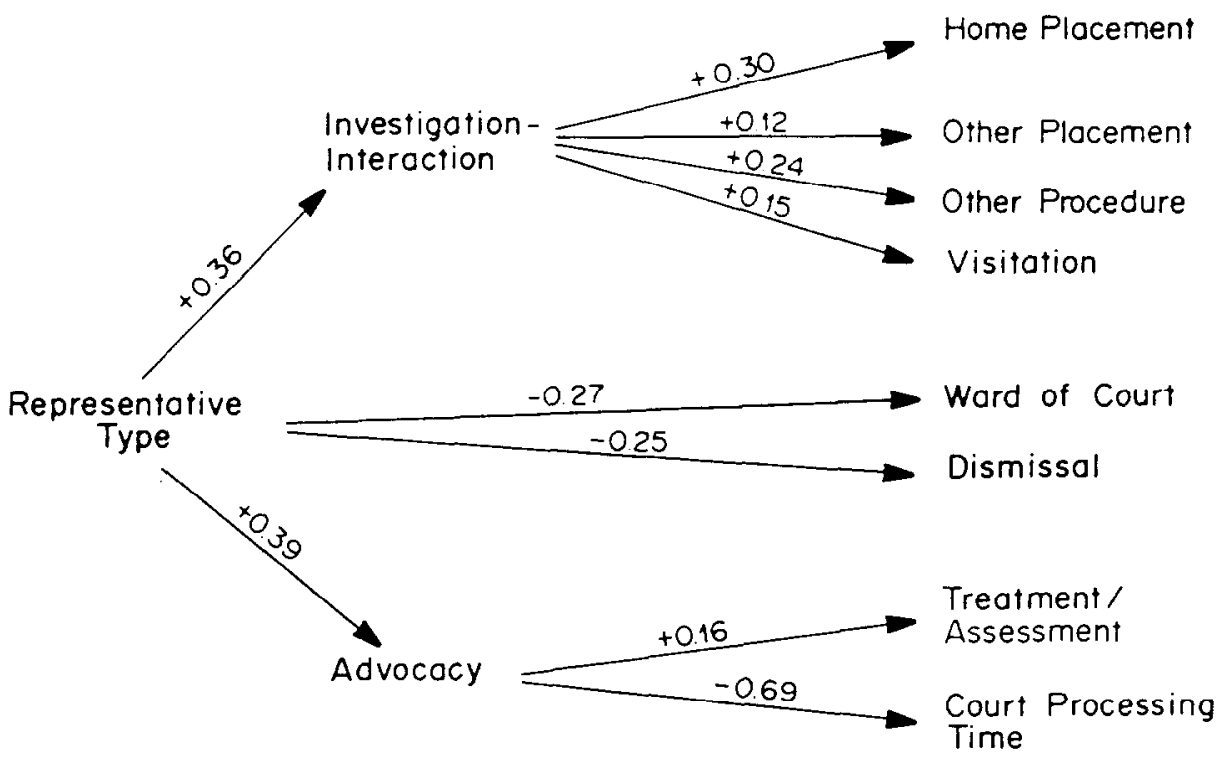

Figure 1. Path Model of the Effects of Type of Representative (Demonstration or Control) and Representative Activity (Process Mleasures)** on Outcome***

* All relationships in the model are expressed as standardized regression coefficients (Beta) and are significant in the 0.10 range.

** Since the Motivation Scale and the Child Scale did not influence outcome, they are omitted.

gressing more rapidly to the decision stage. On average, the demonstration cases reached the first major disposition in 37.9 days, compared with 60.6 days required by the control cases. Although this difference is statistically significant, it is important to note that the path model demonstrates that it was not representation by the demonstration representatives in itself that caused this difference, but rather the fact that demonstration representatives engaged in more advocacy activities.

Interestingly, 30\% of the cases handled by the demonstration group finished the court process within four days (See Table 2). This may have been due to the continuity of representation provided by the demonstration groups. The demonstration representatives would have been able to continue to work toward a resolution of their cases whereas the responsibilities of the control representatives who served at the preliminary hearing would have ended after a single court appearance.

Placement. Home and other placement orders were also affected indirectly the the presence of the demonstration representatives. Demonstration representatives were more likely to score high on the Investigation-Interaction Scale and a high score on this scale was positively and strongly related to home placement and less strongly to other placement. Relative placements were not affected either directly or indirectly by the presence of the demonstration representatives and occurred at approximately the same rate for control and demonstration cases.

We had anticipated that the demonstration representatives' cases would be likely to have more home placements and fewer placements in foster care ordered by the court. That expectation was partially borne out in the increased number of home placement orders which seems to indicate a greater concern for stability and continuity of environment for the child and attempts to make the child safe in his own home whenever pos- 
Table 2. Percent of Cases by Case Type and Length of Time (in days) in Court System

\begin{tabular}{lcccc}
\hline \multirow{3}{*}{ Control } & $0-4$ days & $5-42$ & $43+$ & Total \\
\cline { 2 - 5 } & $2.4 \%$ & $43 \%$ & $55 \%$ & $100 \%$ \\
Demonstration & $(1)$ & $(16)$ & $121)$ & $138)$ \\
& $30 \%$ & $41 \%$ & $30 \%$ & $100 \%$ \\
& $(16)$ & $121)$ & $(16)$ & $(53)$ \\
\hline
\end{tabular}

sible. A greater number of other placement orders (primarily orders for foster care) in the demonstration cases may indicate that these representatives were more concerned about the placement of the child clients and consequently were more likely to ask for a court order regarding placement whether the move was from home to foster care, from foster care to home or some other placement change.

Visitation and Treatment/Assessment. Visitation was also indirectly affected by the presence of the demonstration representatives. Orders relating to visitation were more likely when either the demonstration or control representatives had a high score on Investigation/Interaction. but the demonstration representatives were more likely to have a high score on this scale.

Orders relating to Treatment/Assessment were also indirectly affected by the representative type. Demonstration representatives were more likely to score high on the Advocacy Scale and high scores on this measure were related to more orders for treatment and assessment.

Formal court jurisdiction. Two variables reflecting formal court jurisdiction-ward of court and dismissals - were directly and strongly affected by the type of representative rather than indirectly affected through representative activity. The demonstration cases resulted in far fewer wards of the court $39 \%$ of the demonstration cases compared with $62 \%$ of the control cases). This may indicate a more rapid assessment of the cases and successful diversion of certain cases from the formal court process. None of the demonstration cases diverted from the court process had returned to the court six months later.

However, as the model shows, the demonstration cases, once made wards of the court. were also less likely to be dismissed. By the first major disposition, $37 \%$ of the demonstration group cases were dismissed compared with $56.4 \%$ of the control group $(\chi=3.43$; $p=.06$ ). Orders of dismissal tended to be entered at the preliminary hearing for the demonstration group, 13 of the 21 dismissal orders $(62 \%)$. Of cases not dismissed at the first major disposition, the control cases had significantly more dismissals than demonstration cases within four months after the first major disposition (Demonstration, 30\%; Control, $57 \%), x=5.6, p=.01$.

Thus control cases were more likely to be made wards of the court and then dismissed, whereas demonstration cases, when dismissed, tended to be dismissed without first being made wards of the court. Although demonstration cases were more likely to be dismissed at preliminary hearing, once a case reached dispositional hearing, the demonstration cases were far less likely to be dismissed. This may be attributed to more careful assessment and screening of cases by the demonstration groups at the preliminary hearing stage and perhaps to more watchful advocacy on behalf of a child once made a ward of the court. Continuity of representation may have helped the representatives make a more accurate, earlier assessment of the need for court intervention.

Importantly, a follow up after six months showed that none of the demonstration cases which had been dismissed by the court had returned for further court action. 
Impact on Case Outcome. Other procedural orders. a miscellaneous category that included such court orders as those disposing of motions and amendments to petitions, was also positively associated with high Investigation-Interaction scores, perhaps a further reflection of the increased activity of the demonstration groups.

Another example of the demonstration representatives acceleration of the court process is the timing of no contest pleas. Although the difference in the number of no contest pleas between the two groups is not significant. no contest pleas were entered significantly earlier in the process in the demonstration cases. In $83 \%$ of the demonstration cases in which a no contest plea was entered ( 15 out of 17 cases). the plea was entered at preliminary hearing or at pretrial. compared to $43 \%$ of the control cases $(6$ of 13): in $50 \%$ of the control cases $(7$ of 13$)$ no contest pleas were entered at adjudication/disposition hearings, compared with $11 \%$ of demonstration cases ( 2 of 17 ) no contest pleas. $x-15.1$. $p=.001$.

Overall. the path analysis showed that the demonstration representatives did have an impact on case outcome. Orders of Ward of Court and Dismissal were less likely to occur in the demonstration cases. Cases in which the representatives scored high on the process measure. Advocacy, were more likely to pass quickly through the court system and to have orders related to treatment and assessment. High scores on the process measure, Investigation-Interaction, were positively related to orders of home placement and visitation.

\section{LIMITATIONS OF THE DATA}

The case outcome datal does not address the question of whether particular children were better served by the court because of the efforts of their child advocates. Even if the reader shares the researcher"s assumptions that the best interests of the child are generally served by timely processing of cases. frequent visitation, and diversion from the formal court process consistent with a child's safety. etc.. it does not follow that these outcomes are best for each and every child in each and every case. Sometimes visitation can be harmful to a child or delay in the court proceedings can positively facilitate cooperative resolution of a family problem. Through the training, the research team attempted to instill the need for individualized judgment on behalf of the child and stressed the absence of any pat formula for resolving these troublesome dilemmas. Anecdotal information indicates that the trained advocates did. indeed. exercise individual judgment in their cases. drawing on a variety of approaches to further the interests of their young clients. The evaluation tools, however, do not make these fine distinctions. Outcome data is aggregated and only reveal general trends in case outcomes - trends that are consistent with the early assumptions as to what is "better" for most children and trends consistent with the training provided the demonstration groups. The outcome measures, however, focus on the court process and rest on certain assumptions ats to what court orders indicate successful outcomes for children. The measures used do not reveal whether individual children are better off as a result of the advocacy. More empirical work on the process and effects of advocacy is necessary.

\section{CONCLUSIONS AND POLICY IMPLICATIONS}

The study demonstrates a model of representing children in which the child advocate's role is defined as continuous, aggressive and ambitious, encompassing both the legal and nonlegal interests of the child, and in which training in the role was provided. The demon- 
stration model was successful in improving the quality of representation and, as a consequence, better case outcomes resulted. The demonstration model appears to be a clear improvement over the prior system.

A second major conclusion can be drawn from the study. Since all three demonstration groups provided similar high quality representation. who is trained seems to be less important than that some training take place. Since the improvement in advocacy for children also saved the court resources in the number of hearings and length of time it took to bring a case to a conclusion, the training sessions are likely to be cost beneficial.

Lay persons (nonlawyers) carefully selected, trained and under lawyer supervision performed as well as lawyers and law students in representing children. They certainly performed better than lawyers without special training. Considering the high quality of representation provided by lay volunteers and considering the potential cost savings of such volunteer programs, courts should consider initiating programs relying on nonlawyer representation of children under lawyer supervision with the representation provided by carefully selected and trained volunteers, law students or perhaps social workers, psychologists or graduate students in those disciplines.

Acknowledgment-

Thanks to Sarah H. Ramsey. Associate Professor. Syracuse University College of Law, with whom the author co-authored a more extensive report on this research for law review publication. This report could not have been completed without her careful scholarship and assistance.

Thanks to the many persons who assisted in this study. especially Judge Thomas L. Gadola and Mr. Gerald Thulhammer of the Genesec County Probate Court, Attorney Patric A. Parker who helped train the volunteers and ably supervised them throughout the project: Professor Kathleen C. Faller, University of Michigan School of Social Work: Ms. Nancy Mathiowetz, statistical consultant, JoAnn Townsend and Arthur Rose, research assistants; and David M. Chambers and Robert F. Kelly for their many helpful suggestions throughout the study.

\section{NOTES AND REFERENCES}

1. U.S. DEPT. OF HEALTH AND HUMAN SERVICES (DHHS). Representation for the Abused and Neglected Child: The Guardian Ad Litem and Legal Connsel. DHHS Publication No. (OHDS) 80-30272. Special report from the National Center on Child Abuse and Neglect. Washington, DC (1980).

2. INSTITUTE OF JUDICIAL ADMINISTRATION. AMERICAN BAR ASSOCIATION. Jurenile Jistice Standards: Standards Relating to Counsel for Private Parties. Ballinger, Cambridge, MA (1980).

3. FRASER, B. G. Independent representation for the abused and neglected child: The guardian ad litem. California Western Law Review 13:16-45 (1976).

4. Note: The non-lawyer guardian ad litem in child abuse and neglect proceedings: The King County. Washington, experience. Washington Law Review 58:853-870 (1983).

5. DAVIDSON, H. A.. Repre'senting Children and Parents in Abuse and Neglect Cases. ABA National Legal Resuurce Center on Child Advocacy and Protection. Washington DC (1980).

6. U.S. DFPARTMENT OF HEALTH AND HUMAN SERVICES (DHHS), Representasion for the Abused and Veglected Child: The Guardian ad Litem and Legal Counsel, p. 10.

7. JOHNSON, C. L. Mach Wore to Do about Something: The Guardian ad Litem in Child Protection Proceedings. Regional Institute of Social Welfare Research, Inc., Athens, GA (1979).

8. BERNSTEIN. B. E. The attorney ad litem: Guardian of the rights of children and incompetents. In: Who's Watching the Children? A Collection of Readings on the Legal Aspects of Child Welfare Services for Neglected Children. C. Simmons (Ed.), pp. 40-45. School of Applied Social Sciences, Case Western Reserve University, Cleveland (1980).

9. KNITZER, J. and SOBIE. M. Law Guardians in New York State: A Sull of the Legal Representation of Children. Monograph. New York State Bar Association (1984)

10. INSTITUTE OF JUDICIAL. ADMINISTRATION. AMERICAN BAR ASSOCIATION Juenile Justice Standards: Standards Relating to Counsel for Private Parties, p. 51.

11. FRASER, B. G. Independent representation for the abused and neglected child: The guardian ad litem. $p$. 30.

12. RAY-BEIIINESKI, C. Court-appointed special advocate: The guardian ad litem for abused and neglected children. Juvenile and Family Court Judges 29:65-70 at 66. stating that "there is considerable misunderstanding over the definition and role of the guardian ad litem. specifically in maltreated children cases." (1978).

13. FRASER B. and MARTIS. H. An advocate for the abused child. In: The Abused Child. H. Martin (Ed.), pp. 165-178 at 175. Ballinger, Cambridge. MA (1976). 
14. DAVIDSON. H. A. Representing Childen and Parents in Abuse and Veglect Cases. p. 13.

15. Washington Lat $R^{2}$ vit' 58.862 (1983).

16. For information on programs. contact the Court-Appointed Special Advocates Committee. National Council of Family and Juvenile Court Judges, Judicial College Building. Lniversity of Nevada. Reno, Vevada 89507.

17. STEKETEE. J. P. The CIP story. Jutenile Justice 28:1 (1977).

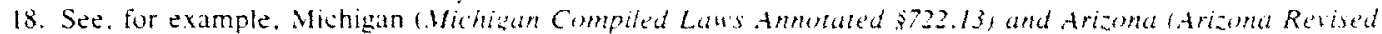
Sintute's Annowat $\$ 8.515,04)$.

19. BLADY. W. Children at Risk: Waking a Difference Thomph the Caye Project. National Council of Jewish Women. 15 East 26th St. New York. NY 10010119821

20. Personal communication, National Association of Court Appointed Special Advocates, Seattle. WA March (1986).

21. Information on current programs can be ohtaned from the National Court Appointed Special Advocates Association. 909 N.E. 43rd St. Sulte 204. Seaule. WA 98105.

27. INSTITLTE OF JUDICIAL ADMINISTRATION. AMERICAN BAR ASSOCIATION. JuEnte Justice Standards, pp. $73-74$.

23. JOHNSON. C. L.. THOMAS. G. and TURE.4. E. Implementing the guardian ad litem mandate: Toward the development of a feasible model. June'nile and Family Court Journal 3 (1980).

24. Personal communication with Jay Olsen. NCCA.Y. October 31 (1985).

25. WNOOKIN. R. In the Interest of Children, p. 18. W. H. Freman. Vew York (1985).

26. HOROWITZ, R. and DAVIDSON, H. Le wal Rights of Children, s06.04. McGraw-Hill. Colorado Springs. CO (1984).

27. GOLDSTEIN, J.. FREUD. A. and SOLNIT. A. Beyond the Best merests of the Child, pp. 40-49. The Free Press. New York (1973).

28. INSTITUTE OF JUDICIAL ADMINISTRATION, AMERICAN BAR ASSOCIATION, Ju'nile Justice

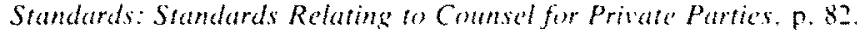

29. GOLDSTEIN. J., FREUD, A. and SOLNIT. A. Beyond the Best Interests of the Chid. pp. 53-64.

30. Federal Adoption Assistance and Child Weltare Act of 1980 . P.L. 961-272, 42 U.S.C.A.. \$6756 5 (A). adyocates the use of the least restrictive (or most family-like) setting available in close proximity to the parents" home. consistent with the best interest and special needs of the child.

31. ISAACS. J. L. The role of counsel in representing minors in the new family court. Buffalo Law Reriew 28:506-507 (1963).

32. INSTITUTE OF JUDICIAL ADMINISTRATION, AMERICAN BAR ASSOCIATION, JWente Justice Standards: Siandards Rolating to (ounsel for Private Partics, pp. 1.5 and $\$ 3.1(\mathrm{~b})$. Most recent commentators have urged that advocates for the child take the position identified by the youthful client when the young person is reasonably capable of making judgments.

33. RAMSEY, S. H. Representation of the child in protective proceedings: The determination of decisionmaking canacity. Family Law Qharterly 17:287 11983)

34. LONG, L. When the client is a child: Dilemmas in the lawyer's role. Jomand of Family Lam 21:607. 611.

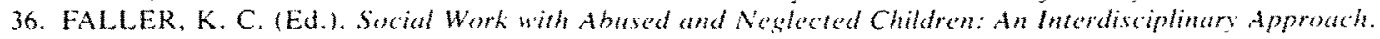
The Free Press. New York (1981).

37. DUQUETTE, D. N. Liberty and lawyers in child protection. In: The Bathered Child, (3rd ed.). C. H. Kempe and R. E. Helter (Eds.), pp. 316-329. The University of Chicago Press. Chicatgo. IL (1980)

38. In the control group there were significantly more older children lage 12 and older) than in the demonstralion group and the demonstration group had a larger proportion of very young children (infant 103 years) than did the control group. However. the mean age of children in the control group was 10.1 years compared to a mean of 7.9 years for the demonstration group, a difference that was not statistically significant. To compensate for bias that these age differences might introduce in subsequent analyses, age was used as at control variable in the early stages of all multivariate analysis and was kept in those models in which it was found to have a signiticant impact on outcome variables.

39. In order to enhance the interpretability of subsequent multivariate andlyses, the factor scales were estimated in a manner that makes each scale statistically independent of the other (the orthogonal solution). Because the scales have been standardized, each has a mean of zero and a standard deviation of one. The factor table is available on request from the author.

40. Because the number of cases in the sample is small and because we felt that our quasi-experimental design required a more rigorous multivariate test of program impacts on the outcome variables, a more liberal inclusion level in the 10 range. rather than the traditional .05 level of statistical significance was chosen. This choice allows us to deteet program effect in well-controlled models, while at the same time recognizing that the small size reduees the odds that program effects would be found at higher levels of statistical signiticance.

41. or control cases with more than one attorney. the performance of the attorney who represented the child at the first major disposition was used. (Demonstration cases had only one representative per case.) 